\title{
Corporate Social Responsibility In The United States And Europe: How Important Is It? The Future Of Corporate Social Responsibility
}

Almerinda Forte, St. John's University, USA

\begin{abstract}
Corporate social responsibility plays an important role in a firm's life in the U.S. today. It is not enough for companies to generate a profit. U.S. citizens expect them to generate a profit and conduct themselves in an ethical and socially responsible manner. The U.S. Sentencing Commission Guidelines help organizations facilitate this expectation, which is vital for corporate growth and maintaining a competitive edge. Managers who deal with ethical and social responsibility problems oftentimes aren't dealing with optimal solutions. Managers often settle for solutions that suffice or cause the least harm. Managers charged with choosing the ethical or socially responsible path often face problems with no clear solution.
\end{abstract}

Since the formation of the European Union, corporate social responsibility has garnered heightened attention in Europe. This is evidenced by their development of sustainability strategies. The Sustainable Development Strategy for Europe was approved in June 2001. It stated that social cohesion, environmental protection, and economic growth must coexist.

This paper compares corporate social responsibility (CSR) in Europe to CSR in the United States. It also examines today's three corporate social responsibility models: the shareholder value model, the stakeholder model and the business ethics model. This paper also addresses Wayne Visser's (2010) five principles which he considers the future of corporate social responsibility, Aras and Crowther's (2011) theory that an organization should be held accountable to the external environment, and the rationale for new paradigms for the future in companies worldwide.

Keywords: Corporate Social Responsibility in US \& Europe; Future Corporate Social Responsibility

\section{INTRODUCTION}

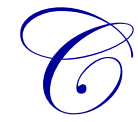

orporate social responsibility (CSR) concerns both the public and the business community. The current global financial crisis has ignited public concerns with corporate social responsibility. Wall Street's greed, executive overpay, the moral hazard of financial derivations, and excessive risk-taking have been publicly questioned and condemned. Attention has also focused on deciphering how different companies and different countries understand corporate social responsibility. Before the financial crisis, Enron and World.com drew attention to the current state of corporate social responsibility. Later, the potential failure of the banking system intensified and expanded such attention globally.

The traditional three corporate social responsibility models have been questioned on their effectiveness. It has also been noted that companies and countries differ in their understanding and development of corporate social responsibility due to their variety of social values and cultures. This paper examines the traditional model of corporate social responsibility and how corporate social responsibility develops in various countries. It also addresses how corporate social responsibility should develop and operate in the future in order to benefit companies, communities, and society as a whole. 
Studies show that countries differ in their dedication to being perceived as socially responsible; Williams and Aguilera (2006) state that the absence of a universal definition of CSR may be a reason. Maigman and Ralston's (2002) study found that businesses in the U.S., U.K., the Netherlands, and France do not ascribe equal importance to projecting a socially responsible image. They found that businesses in different countries employ different devices to communicate their CSR principles, processes, and stakeholder issues.

U.S. businesses freely acknowledge their ethical and social obligations. They accept the idea that businesses bear economic, legal, ethical, and discretionary responsibilities. Williams (2010) defines discretionary responsibility as the presumption that a company will voluntarily serve society. Such service reaches beyond economic, legal, and even ethical responsibilities. Most businesses support the fight against hunger. The U.S. Sentencing Commission's Guidelines for Organizations in the U.S. helps facilitate such goals. Almost all businesses are covered. This includes labor unions, partnerships, unincorporated organizations and associations, incorporated organizations, nonprofits, pension funds, trusts, and joint stock companies.

In July 2001, the European Commission presented the Green Paper. This laid the foundation for CSR in Europe. The Green Paper "Promoting a European Framework for CSR" (Commission of the European Communities, 2001b) states that corporate social responsibility is a "concept whereby companies integrate social and environmental concerns, their business operations, and their interaction with their stockholders on a voluntary basis" (Tencati, 2006).

\section{PROS \& CONS OF CORPORATE SOCIAL RESPONSIBILITY}

Swanson (1995) identified three motivations that encourage firms to commit to CSR. The first motivation is strictly utilitarian; that is, CSR can be utilized to enhance profits, raise investment returns, and increase sales volume. At times, corporations adopt CSR policies in order to satisfy their stakeholders' behavioral norms. This second motivation is termed a negative duty approach. In contrast, the third motivation - the positive duty approach - weaves CSR principles into the corporation's identity. This motivation evidences itself in businesses which are proactive, aiming for a positive impact on society.

Public expectation necessitates that firms commit themselves to social responsibility. The public now expects businesses to pursue social objectives in addition to economic ambitions. Long-term profits also encourage such commitment. Businesses viewed as socially responsible are more secure in long run profits. Dedication to CSR enhances community relations and contributes to a favorable public image.

Business ethics are a must; business must have a conscience. Public image is a crucial component in the livelihood of a firm. More customers, better employees, access to money markets and other benefits are linked to a favorable public image. Socially responsible corporations can provide a better environment, a better quality of life, and a more desirable community. CSR results in less government regulation. Social responsibility benefits longterm stock prices as the market deems socially responsible firms less risky.

In his article "The 7 Principles of Business Integrity," Robert Moment maintains that companies must now prove themselves in order to build lasting business relationships with consumers. He states that businesses must give back to their communities. According to Moment, such involvement will endear companies to their local markets. He also states that employees must be treated with respect and experience fair working conditions. Firms must establish fair hiring practices and promote a non-discriminatory workplace. The resulting environment will improve workplace morale and encourage camaraderie.

Clarkson (1995), Maignan, Ferrell, and Hult (1999), and Wood \& Jones (1995) all assert that businesses bear no responsibility to society. Rather, their sole responsibility is to their stakeholders. This school of thought maintains that violation of profit maximization argues against social responsibilities. The classical viewpoint holds that businesses' main responsibility lies in maximizing profits. Its interests are purely economic, with social responsibilities only diluting its purpose. They also point out that socially responsible activities can be costly and that these costs may be passed on to consumers through higher prices. Businesses are given more power when they pursue social goals and they may be poorly qualified to cope with social issues. Companies lack a direct line of 
social accountability. Society, they say, hasn't issued a broad mandate for businesses to involve themselves in social issues.

In his Forbes October 22, 2008 article “CSR Doesn't Pay”, David Vogel cautions that CSR may not lead to monetary gain. Profit earning companies' main focus is maximizing shareholder value. He states that businesses would have to satisfy the financial expectations of company owners alongside other stakeholders' social and environmental demands. Vogel concludes that businesses would find this challenging at best.

\section{TRADITIONAL MODELS}

Today, CSR focuses on three models - the shareholder value, the stakeholder, and the business ethics. The shareholder value model follows Milton Friedman's (1970) belief that businesses' only social responsibilities are to increase profits and obey the law. The stakeholder model focuses on social responsibilities that a corporation bears for its stakeholders that only impact the corporation. The business model focuses on social obligations and the moral duty business has to society. Based on William Sun and Lawrence Bellamy's thesis, the future success of CSR depends on businesses focusing on the interconnectedness of all society members and the subsequent mutual interests of self and others. They state that business should not be separated from society, but integrated into it. They maintain that the purpose of business is serving the common good.

Sun and Bellamy (2010) criticize the shareholder value model's narrow scope. This model views businesses as focusing only on maximizing profits. Likewise, they assert that the stakeholder model falls short since it only recognizes and prioritizes the limited interests of select groups within the company, specifically groups holding a large influence. Sun and Bellamy indicate that this model enabled the financial industry to manipulate policies. This model provided them the opportunity to abuse mortgage underwriting standards and to justify the transfer of high risk loans to investors in order to pursue their own financial gain. In their view, this model destroys CSR. It fails to require businesses to widen their social interests beyond a few specific stakeholder groups within the company. Jackson \& Carter (1995) state that the business ethics model is ideal for capitalism. Business is often criticized as being "an inherently amoral system, concerned only with money-making money" (Jackson \& Carter, 1995, p. 883). Sun and Bellamy state that this model assigns firms two roles - the private economic role and the public social role. The two roles have different responsibilities which differ in norms, values and codes. Firms would thus need to hold both business values and ethical values. Sandberg (2008) states that "there is a genuine difference between matters of business and matters of ethics, at least insofar as there is a genuine difference between descriptive and normative matters"

(p. 227).

According to Sun and Bellamy (2010), the limitation of CSR's current focus is that business is without ethics. They believe we need to rethink the CSR concept, that we must move away from CSR as embedded in a social, political and economic context. CSR should integrate business and society rather than separate business from society.

\section{VARIOUS COUNTRIES' CSR PERSPECTIVES}

Fiori, diDonato and Izzo (2007) investigated the effect of voluntary CSR on stock prices in their article titled "Corporate Social Responsibility and Firms' Performance: An Analysis on Italian Listed Companies." They analyzed whether corporate social responsibility disclosure increases stock prices. Utilizing a sample of Italian listed companies, this study measured the correlation between CSR reports and stock prices over the course of three years. The study's rationale was that a "bad" social impact could increase the firm's vulnerability. This could lead to undesirable relationships with money and stockholders. This, in turn, would affect a corporation's reputation. The study investigated how CSR affects a firm's performance. The research also examined the perception of CSR by investors and stockholders. The two parameters of CSR were employment and environment. Employment included health and safety systems, employee training and development, equal opportunity policies, systems for employee relations and systems for job creation and security. Environmental elements included environmental policies, environmental management systems, environmental reporting and community performance. The research consisted of twenty-five firms operating in different sectors, excluding banks and insurance companies that began to 
prepare CSR reports in 2006. The study found that Italian firms are increasing their commitment to social responsibility. They are paying more attention to preparing good CSR reports. Only a small number of Italianlisted companies engage in CSR reporting. Only twenty-five firms of the Italian-listed companies (excluding banks and insurance firms) have drawn up CSR reports in the last three years (even less before). Italian firms and their stockholders are largely disinterested in CSR issues. The research found that stock prices are influenced more by economic and financial performance. They reported that since 2006, an increasing number of firms are interested in producing CSR reports. The empirical evidence found that Italian firms' stock prices remain unaffected by CSR reports, even when firms display heightened interest in and devotion to these issues. In Italy, CSR remains a relatively new concept. Most investors show little awareness of the matter. The study found that the quality of CSR disclosure can't be measured easily. Also, there exists a lack of generally accepted principles and most firms utilize CSR disclosure as a means to advertise. They avoid giving pertinent information. Finally, the researchers found that Italian investors focus on short-term results, while the impact of CSR becomes more apparent with time.

Antonio Tencati (2006) also conducted an empirical survey on CSR in Italy. He started his research in 2002. The sample size consisted of 395 enterprises. Tencati gathered descriptive data from Italian entrepreneurs and managers regarding their knowledge of corporate responsibility and their interpretations of it. The sample was selected among companies sensitive to CSR. Tencati found that fewer than half (45\%) were familiar with the "Green Paper" used by the EU to promote CSR. His research exposed numerous benefits that would encourage companies to pursue socially responsible behavior. The most common advantages cited were enhancement of company image (90\%), potential to improve community relations $(76 \%)$, and the particular inclinations of top management (56\%). Only one company (1\%) named pressures from clients or suppliers as incentive to initiate social responsibility. Tencati pinpointed numerous obstacles discouraging firms from instituting CSR. These obstacles were: time constraints (61\%), inadequate human resources, financial restraints (38\%), and low topic awareness $(31 \%)$. His research found factors which could increase attention to CSR in days and years to come, such as monetary incentives (48\%), CSR information dissemination (47\%), enhanced company image (47\%), failure to consider the possibility of increased access to financial resources (7\%), and improved relations with public authorities (17\%). Forty-three percent of the sample indicated they planned to increase their firm's CSR activities. Fifty-eight percent of the sample stated that CSR would remain at its present level.

Maignan and Ralston (2002) examined how U.S. and European businesses communicate CSR on their websites. They studied the websites of 400 firms within the U.S., France, the Netherlands, and the U.K. They evaluated the extent to which businesses attempt to convey a socially responsible image and the nature of the motivation, processes, and issues considered in attempting to paint a portrait of good corporate citizenship. The research found that the U.K. and U.S. websites featured CSR principles more so than their French and Dutch counterparts. The U.K. and U.S. firms were much more willing to address CSR principles, processes, and issues than either the French or Dutch firms. Maignan and Ralston's research indicates that the inclusion of CSR on websites is not associated with any particular industry.

Maignan and Ralston's (2002) study found that each country favored different motivating CSR principles. The U.S. firms presented social involvement as reflective of their core values. In contrast, this was the justification used least by European businesses. According to the study, European firms discussing CSR on their websites promoted CSR as value-driven. This research found that performance-driven CSR was the second most frequently named motivation within the U.S. The U.K. favored performance-driven CSR. This view, deeming CSR good business, was adopted by quite a few French and Dutch organizations as well. The study found that European firms introduced CSR in their firms in response to stakeholder scrutiny and pressures. In France and the Netherlands, they found that fewer businesses mentioned CSR. These countries differentiated their stated motivations more so than either the U.S. or the U.K. In summary, the value-driven approach led within the U.S. The performance-driven perspective, mixed with the stakeholder-driven view, dominated in the U.K. Finally, while the value-driven perspective found popularity in the U.S., it was not as popular there as it was in the European countries that participated in this study.

Maignan and Ralston (2002) found that the U.S. and U.K. were likelier to list ethics codes as CSR processes than either France or the Netherlands. The U.S. companies discussed giving primarily to their communities through philanthropic programs. The Dutch and French businesses illustrated their commitment to 
CSR by highlighting their environmental programs. Maignan and Ralston found that French and Dutch firms referred to volunteerism. This study showed that in France, quality programs were mentioned more often than philanthropic programs as illustrative of responsibility. The Netherlands also illustrated sponsorships. French and Dutch firms appear to construct a socially responsible image by headlining practices connected with the production process and traditional promotions. They limited the environmental effect to their operations, quality management, and sponsorships. The U.S. firms reached beyond basic production and promotion activities. They attempted to look socially responsible by showcasing their philanthropic programs and volunteerism. The U.K. firms utilized a moderate approach compared to the French, Dutch and U.S. businesses. The U.K. emphasized traditional production and promotion-oriented programs. Their CSR discussed sponsorships, health and safety initiatives. In summary, this study concluded that the selected countries favored varying CSR processes to portray a socially responsible image.

Businesses in Maignan and Ralston's (2002) research specified three principal stakeholder groups community, customers and employees. Their research found that all four countries cited community stakeholder issues most often. U.S. firms mentioned quality of life and education. The U.S. businesses tended to zero in on issues that were not directly connected to their activities. They paid attention to arts, education, culture and quality of life. The U.S. firms focused on issues connected to the well-being of the community. They put aside the initiative closely linked to their productive operations. Environmental protection was the number one issue cited by the French, Dutch and British businesses. The French and Dutch mentioned it the most. French organizations highlighted environmental protection as well as product and service quality. The French firms focused on the areas of social responsibility that were connected to their productive activities. Dutch firms cited the protection of the environment, arts and culture, and employees' health and safety. British businesses demonstrated equal concern for numerous issues. They frequently spoke of arts and culture, environmental protection, education, safety, and quality of life. The U.K. businesses highlighted their devotion to general community issues. They emphasized issues which impacted their productive operations. In summary, the four countries participating in Maignan and Ralston's study focused their commitment on different stakeholder issues.

Tinike Lamboody (2010) points out that in Europe, the Dutch model includes expansive CSR specifications in corporate governance codes. Lamboody states that this differs greatly from the United Kingdom's approach. CSR became explicit and concrete in the UK with the Frijins Code published in 2008 and taking effect in 2009. CSR encourages long-term business plans, the internationalization of external costs, corporate accountability, stakeholder involvement, and the transparency of environmental, social and governance (ESG) factors. Lamboody states that this falls in line with the Dutch concept of the corporate role in society to meet the needs of both stakeholders and society alike. Lamboody views the inclusion of CSR in the Dutch corporate governance code as a positive step. He believes that it can assist boards in guiding companies toward sustainable business with a longterm view. Lamboody believes there is still room for improvement of the Frijins Code. He states that corporate governance will and undoubtedly needs to develop further as a tool supporting CSR.

According to Justyna Berniak-Wozny (2010), Polish companies need to implement CSR concepts. They can start by rejecting corruption and unethical behaviors in business circles. Berniak-Wozny believes that Polish firms need to expand the dimensions of their management methods, starting with conduct codes. They also need to implement CSR strategies according to global CSR standards. Alternatively, they can instigate social involvement by partnering with NGOs. Firms should supply reliable, systematic reports detailing their social effects by including CSR sections on their websites and by providing CSR documents consistent with international reporting standards. Berniak-Wozny recommends that public administration should promote and popularize CSR concepts. They can reward best practices and support courses dealing with ethics education and corporate social responsibility. Nongovernmental organizations (NGOs) can form a stronger network by supporting positive actions among business organizations. They can offer CSR educational programs, conferences and seminars in cooperation with business organizations, media, NGOs, public administrations and universities. This is needed to help facilitate the development and implementation of CSR concepts in Poland. Media should also inform the Polish society about the socially responsible activities implemented by business. According to Berniak-Wozny, the Polish economy must face the fact that socially responsible operations are indispensible in improving companies' competitiveness and strengthening brands. 


\section{THE FUTURE OF CORPORATE SOCIAL RESPONSIBILITY}

According to Wayne Visser (2010), the future of CSR must incorporate five principles; namely, creativity, scalability, responsiveness, glocality, and circularity.

Creativity is the first principle in Visser's model. Visser asserts that in order for CSR to succeed, we need innovation and creativity. Thomas S. Kuhn (1970) states that change occurs only through changed perception. A new paradigm or way of thinking is found. He states that business is naturally creative and innovative. Visser locates today's business in the "Age of Responsibility." He believes that businesses should direct their creativity toward resolving social and environmental problems. For example, Visser deems Apple extremely creative, but Apple's iPhone, he remarks, contributes scant benefit to society. In contrast, Visser refers to Vodafone's M-PESA innovation by Safaricom in Kenya. Their product enables consumers to transfer their money via text. Visser maintains that this newfound ability has empowered Kenya, since eighty percent of its population has no bank account. This product allows money to flow into the country through worldwide avenues other than foreign aid. According to Visser, if businesses aim their creativity toward pressing social needs, it will accelerate entrance into the Age of Responsibility.

Scalability is Visser's second principle. This principle states that the largest sustainability problems are climate change and poverty. They are so urgent that no CSR solutions can match their scale and urgency. Ethical consumerism (organic and fair-trade) has been a long-standing problem. According to Visser, corporations and supply chains have been scarcely affected. Visser uses Wal-Mart as an example of scalability. Wal-Mart decided that in the future, all Wal-Mart cotton products will be organic. They further decided that all of their fish will be MSC - certified. Visser states that scalability is not restricted to the retail sector. Financial corporations have always been philanthropic, granting loans to the impoverished.

Visser's third principle is responsiveness. Visser notes that climate change threatens sustainability within the fossil fuel industry. Major oil companies assembled as The Global Climate Coalition. A lobby group, known as the Kyoto Protocol, was created to combat the science of climate change and thwart the international policy response. Since 2005, The Prince of Wales' Corporate Leaders Group on Climate Change has lobbied for more aggressive climate legislation within the U.K. and EU, as well as internationally. They hold that carbon emission reductions between $50 \%$ and $85 \%$ are necessary by 2050. CSR responsiveness also requires heightened transparency. This includes transparency in reporting mechanisms, such as the Global Reporting Initiative and Carbon Disclosure Project and transparency through sharing pivotal intellectual resources. The Eco-Patent Commons provides one example of transparency. It makes technology patents available free of charge in order to help reduce waste, pollution, global warming and energy.

Glocality is Visser's fourth principle; that is, global localization. World companies must be schooled in understanding local contexts. Their solutions must adhere to local standards, while remaining true to universal principles. Based on this principle, both premium brands and cheap generic drugs can contribute toward solving global health issues.

Visser's fifth principle is circularity which means that businesses need to feed and replenish their social and human capital through education and training and through nurturing community and employee well-being.

Visser maintains that the purpose of business is serving society. He believes that businesses can serve society by supplying safe, high quality products and services which boost well-being. He believes that well-being can be enhanced without sacrificing ecological or community concerns. Visser utilizes David Packard's statement to enforce his point - "Why are we here? Many people assume wrongly, that a company exists solely to make money. People get together and exist as a company so that they are able to accomplish something collectively that they could not accomplish separately - they make a contribution to society" (Visser, 2010).

Aras and Crowther theorize that an organization should be held accountable to the external environment, not just its shareholders. They also view sustainability as more than financial and environmental, adding social and cultural as well. Aras and Crowther view corporate accountability as extending to all stakeholders. This increases the expectations of corporate governance in organizations. 
Coewn, Ferreri, and Parker (1987), Gray, Javod, Power, and Sinclair (2001), and Burke and Longsdon's 1996 studies all demonstrated the benefits of corporate social responsibility. According to Aras and Crowther (2011), corporate governance stretches beyond investor relations to include all stakeholders, including the environment and society. Improved understanding of the inter-relationships between social responsibility, sustainability and corporate governance will lead to better corporate governance. This will lead to better economic performance. These scholars perceive that the current economic crisis has intensified the importance of governance. They further argue that the crisis illustrates CSR's vital role in governance as well as its link to sustainability.

\section{CONCLUSION}

Research shows that culture plays a definitive role in corporate social responsibility. For example, CSR policies are more prevalent in countries with social democratic traditions. Richard Welford's (2004) research titled "Corporate Social Responsibility in Europe, North America and Asia" exposed noteworthy links between culture and CSR policies. Such policies are found more often in countries with social democratic traditions. Examples include Germany, Norway and Canada. He also discovered connections between CSR and economic development. The more developed the country, the likelier it is to engage in CSR policies. Welford found that Germany and the U.K. lead Europe. Philanthropy reaches its height in North America. Canada places particular emphasis on education. Maignan and Ralston's (2002) study found the value-driven perspective far less popular in Europe than in the U.S. The European countries favored the traditional production and promotional oriented activities. They also found that countries favored different CSR initiatives in order to promote a socially responsible image. Businesses in the U.S., U.K., the Netherlands and France emphasized their dedication to different stakeholder issues.

The more companies and investors realize that medium to long-term returns hold equal importance to shortterm returns, the more they will realize that CSR benefits both their image and their livelihood. Fiori, diDonato and Izzo's (2007) study titled "Corporate Social Responsibility and Firms' Performance: An Analysis on Italian Listed Companies" and Tencato's (2006) study titled "Corporate Social Responsibility In Italy: State of the Act" provide prime examples of companies and investors who need to change their perspectives in order to have well developed, grounded forms of CSR. These companies tend to adopt the shareholders' model. This model maintains that a company's main goal is maximizing shareholder profits (Williams, 2012). Perhaps a better model would be the stockholders' model which theorizes that management's ultimate goal - long-term survival - is reached by meeting the needs of multiple corporate stockholders (Williams 2010). Businesses in all countries should benefit society beyond their economic, legal and ethical responsibilities. Discretionary responsibility is a must in order to advance the long-term survival of businesses.

Corporate social responsibility provides a crucial element in a corporation's image and livelihood. Globalization is a reality. Globalization includes economic, political, social and cultural changes. The financial crisis emphasized the inter-relationships of countries cultivated through the globalized economy. The corporate scandals surrounding Enron and World.com and the collapse of AIG and the banking system affect not only the United States, but industries across the globe. Therefore, it was necessary to bail them out. It was essential in order to ensure global economic survival. Society, as a whole, is interconnected. The business model focuses on social obligations and moral duties that businesses have to society. According to Sun and Bellamy, corporate social responsibility needs to be redirected toward integrating business into society rather than separating the two. Visser's five principles for the future of corporate social responsibility and Aras and Crowther's theory that an organization should be held accountable to the external environment have earned merit due to the interconnection of industries in today's society. We realize that corporate social responsibility varies widely from company to company and country to country. There are still many industries and countries that are underdeveloped in this area. Corporate social responsibility has been linked to economic development. Whether they want to or not, companies making up the global economy may be forced into considering these theories. As a globalized society, we experience our interconnection on a daily basis. On the day that Berlusconi showed signs of leading Italy's election, the United States market responded with a sell off. The Italian economy impacts the European Union, which in turn affects the United States due to globalization, the interconnection of the economy. The same was experienced with Greece's economic problems. Our debt also impacts the globalized economy. The globalized economy may not be ready to consider these new paradigms quite yet, but in the future it is possible that corporate social responsibility will be fully integrated into society. The business model may be used. Organizations will be held accountable to the external 
environment. Corporate governance will include all stakeholders (investor relations, environment and society). Visser's five principles (creativity, scalability, responsiveness, glocality, and circularity) may be part of the corporate social responsibility model for businesses throughout the globalized economy. We may not see this in our lifetime, but these theories fit the interconnection of the economy. The globalized economy may not be eager to embrace these new paradigms, but the fact that they have been thought through and put to paper promises the possibility of future consideration.

\section{AUTHOR INFORMATION}

Dr. Almerinda Forte is an Associate Professor and Chairperson for the Division of Administration and Economics at St. John's University. She received her Ph.D. from New York University. Dr. Forte has presented papers at several business ethics conferences and international business conferences. She has published several articles in the "Journal of Business Ethics," "International Business and Economics Research Journal," "Journal of Diversity Management," "Journal of International Education Research" and in "Contemporary Issues in Business Ethics" (2007) published Chapter 4 entitled Business Ethics And The Corporate World. In addition to teaching, she was awarded a Senior Specialist Fulbright and has been appointed a Vincentian Research Fellow. Dr. Forte brings to the classroom her experience from numerous companies, including Merrill Lynch, Pierce, Fenner and Smith and The New York State Society of CPA's. E-mail: fortea@stjohns.edu

\section{REFERENCES}

1. Aras, G. and Crowther, D. (2011). Governance And The Management Of Global Markets. In G. Aras, D. Crowther (Eds), Developments in Corporate Governance and Responsibility (Vol. 2). Governance in the Business Environment (pp. 3-21). UK: Emerald Group Publishing Limited.

2. Berniak - Wozny, J. (2010). Corporate Social Responsibility In Developing Countries: Polish Perspective. In W.Sun, J. Stewart and D. Pollard (Eds), Critical Studies on Corporate Responsibility, Governance and Sustainability (Vol. 1). Reframing Corporate Social Responsibility: Lessons from the Global Financial Crisis ( pp. 271-302). UK: Emerald Group Publishing Limited.

3. Clarkson, Max B. E. (1995). A Stakeholder Framework for Analyzing and Evaluating Corporate Social Performance. Academy of Management Review, 20 (1): 92-117.

4. Dewing, I.P. and Russell, P.O. (2006). Corporate Governance - Regulation and Reform: The Actuarial Governance of UK Life Insurers. Corporate Governance: An International Review, Vol.14, No.3, pp. 172180, May.

5. Fiori, G., diDonato, F. and Izzo M.F. (2007). Corporate Social Responsibility and Firms Performance. An analysis on Italian Listed Companies. Luiss Guido Carli University, Italy. Luiss Guido Carlo, Luiss Homepage/Luiss Library page. Retrieved from http://eprints.luiss.it/374/1/Fiori_2007_03_open.pdf or http://ssrn.com/abstract=1032851 or email: fizzo@luiss.it

6. Friedman, M.(1970,September 13), The Social Responsibility of Business is to Increase its Profits. The New York Times Magazine, Copyright @ 1970 by The New York Times Company.

7. Hooghiemstra, R. (2000). Corporate Communication and Impression Management - New Perspectives Why Companies Engage in Corporate Social Reporting. Journal of Business Ethics, 27: 55-68.

8. Kuhn, T.S. (1970). The Structure of Scientific Revolutions Second Edition, Enlarged. Chicago, The University of Chicago Press.

9. Lambooy, T. (2010). Institutionalization of Corporate Social Responsibility In The Corporate Governance Code: The New Trend of The Dutch Model. In W. Sun, J. Stewart and D. Pollard (Eds), Critical Studies on Corporate Responsibility, Governance and Sustainability (Vol.1). Reframing Corporate Social Responsibility: Lessons from the Global Financial Crisis (pp. 145-179). UK: Emerald group Publishing Limited.

10. Maignan, I., Ferrell,O.C., and Hult, G.T. (1999). Corporate Citizenship: Cultural Antecedents and Business Benefits. Journal of the Academy of Marketing Science, 27(4): 455-469.

11. Maignan, I. and Ralston, D.A.( 2002). Corporate Social Responsibility in Europe and the U.S.: Insights from Businesses' Self-Presentations. Journal of International Business Studies, 33:497-514.

12. Moment, R. (2008). The 7 Principles of Business Integrity. GreatOffers 4u.com For Industrial Products \& Manufacturers. http://www.sellintegrity.com, www.greatoffers4u.com/article/3723 
13. Snider, J., Hill, R.P., and Martin D. (2003). Corporate Social Responsibility in the 21th Century: A View from the World's Most Successful Firms. Journal of Business Ethics 48: 175-187, 2003.

14. Sun, W. and Bellamy, L. (2010). Who Is Responsible For The Financial Crisis? Lessons From A Separation Thesis: In W. Sun, J. Stewart and D. Pollard (Eds), Critical Studies on Corporate Responsibility, Governance and Sustainability (Vol.1). Reframing Corporate Social Responsibility: Lessons from the Global Financial crisis (pp. 101-124). UK: Emerald Group Publishing Limited.

15. Swan, D.L.(1995). Addressing a Theoretical Problem by Reorienting the Corporate Social Performance Model. Academy of Management Review, 20(1): 43-64.

16. Vogel, D. (2008, October 22). CSR Doesn't Pay. Forbes.

17. Welford, R. (2004). Corporate Social Responsibility in Europe, North America and Asia. 2004 Survey Results, JCC, Spring 2005, Copyrighted 2005 by Greenleaf Publishing.

18. Williams, C. A. and Aguilera, R.V. (2006). Corporate Governance and Social Responsibility : A Comparative

19. Analysis of the UK and U.S. Corporate Governance: An International Review, Volume 14, Issue 3,pp 147158.

20. Williams, C. (2010). MGMT. USA, Thomson South- Western.

21. Wood, D.J. (1991). Corporate Social Performance Revisited. Academy of Management Review, 16 (4): 691718.

22. Wood, D.J. and Jones, R.E.(1995). Stakeholder Mismatching: A Theoretical Problem in Empirical Research on Corporate Social Performance. The International Journal of Organizational Analysis, 3(3): 229-267. 
NOTES 